\title{
Az otoscleroticus eredetü hallócsontláncolati fixatiók klinikuma
}

\author{
Kriston Fanni dr. ${ }^{1}$ - Rovó László dr. ${ }^{2}$ \\ Kiss József Géza dr. ${ }^{2}$ - Jarabin János András dr. ${ }^{2}$ \\ 'Jahn Ferenc Dél-pesti Kórház és Rendelőintézet, Fül-Orr-Gégészeti és Fej-Nyaksebészeti Osztály, Budapest \\ ${ }^{2}$ Szegedi Tudományegyetem, Általános Orvostudományi Kar, Fül-Orr-Gégészeti és Fej-Nyaksebészeti Klinika, \\ Szeged
}

\begin{abstract}
Az otosclerosis egy komplex csontremodellinggel járó multifaktoriális, humánspecifikus fülbetegség. A csontos labyrinthust érinti, aminek következtében típusosan a stapes rögzül az ovális ablakban. A betegség során kialakult hallócsontláncolati fixatio által csökken a középfül akusztikusimpedancia-illesztő, -erősítő funkciója, így jellemzően vezetéses típusú halláscsökkenés jön létre. A halláscsökkenés progresszív, a későbbiekben a belső fül érintettségének jeleként sensorineuralis komponenssel egészül ki. Mindezen folyamat egy időben elvégzett hallásjavító mútéttel megelőzhető vagy jelentősen lassítható. A stapessebészet fejlődése átíveli a XX. századot, és bár a főbb, Shea és Marquet által már az 1960-as években lefektetett mütéti lépések meglehetősen konzervatívak, finom módosítások, elsősorban a technikai fejlődésnek köszönhetően, még ma is folyamatosan történnek. Számos tanulmány igazolja, hogy otosclerosisban továbbra is a stapedotomia az elsóként választandó terápiás eljárás. Megfelelő mútéti technikával a légvezetéses hallásban jelentős javulás érhető el, a beszédfrekvenciákon a csont-lég-köz minimalizálható, illetve zárható, ami a betegek életminőségét jelentősen javítja. A jelen közleményben az otosclerosissal kapcsolatban fellelhető magyar és nemzetközi szakirodalmat tekintjük át, kitérve a kórfolyamat legújabb diagnosztikus és kezelési lehetőségeire is. Orv Hetil. 2020; 161(19): 780-788.
\end{abstract}

Kulcsszavak: otosclerosis, hallócsontláncolati fixatio, stapessebészet, stapedotomia

\section{Clinical aspects of otosclerotic ossicular chain fixations}

Otosclerosis is a human-specific ear disease characterised by complex bone-remodelling with multifactorial aetiology. It affects the bony labyrinth capsule and consequently fixates the stapes to the oval window rim. The fixation of the ossicular chain leads to a decrease in the middle ear's acoustic impedance-fitting and amplifier function that leads to conductive hearing loss. The process is progressive and when it involves the inner ear structures, it deteriorates the sensorineural function as well. The course of the illness can be prevented or delayed if hearing reconstructive surgery is performed on time. The development of stapes surgery spans the 20th century, and despite the major surgical steps - laid down by Shea and Marquet in the 1960s - are quite conservative, fine adjustments are still being made mainly due to technical progress. Several studies confirm that stapedotomy remained the first-to-offer therapeutic option in otosclerosis. With an adequate surgical technique, significant improvement can be achieved in the air conduction threshold, the air-bone gap may be minimalized or ceased over the speech frequencies, which significantly improves the quality of life of the patients. In this quest, we reviewed the Hungarian and the international literature as well in context with otosclerosis, with special attention to the newest methods in diagnostics and treatment management.

Keywords: otosclerosis, ossicular chain fixation, stapes surgery, stapedotomy

Kriston F, Rovó L, Kiss JG, Jarabin JA. [Clinical aspects of otosclerotic ossicular chain fixations]. Orv Hetil. 2020; 161(19): 780-788.

(Beérkezett: 2019. december 5.; elfogadva: 2020. január 30.)

\section{Rövidítések}

$\mathrm{ABG}=$ (air-bone gap) csont-lég-rés; $\mathrm{ACBC}=$ (autogenous cortical bone columella) autogén corticalis csontcolumella; $\mathrm{BMP}=($ bone morphogenetic protein $)$ csont morfogenetikus fehérje; $\mathrm{CBCT}=($ cone-beam $\mathrm{CT})$ kúpsugaras $\mathrm{CT} ; \mathrm{CD} 46=$ (cluster of differentiation 46) differenciációs klaszter-46; CHL $=($ conductive hearing loss $)$ vezetéses halláscsökkenés; $\mathrm{CI}=$ cochlearis implantátum; CT = (computed tomography) számító- 
gépes tomográfia; $\mathrm{dBHL}=($ decibels hearing level $)$ decibel hallásszint; GIC $=$ (glass ionomer cement $)$ üvegionomer cement; $\mathrm{HE}=$ hematoxilin-eozin; HRCT $=($ high-resolution $\mathrm{CT})$ nagy felbontású CT; HRQOL $=$ (health-related quality of life) az egészségi állapottal kapcsolatos életminőség; $\mathrm{IgG}=$ immunglobulin-G; LDV = (laser Doppler vibrometry) lézeres Dopplervibrometria; $\mathrm{MHL}=($ mixed hearing loss $)$ kevert típusú halláscsökkenés; MIVIB = (minimally invasive intraoperative laser vibrometry) minimálinvazív intraoperatív lézeres vibrometria; MRI $=$ (magnetic resonance imaging) mágnesesrezonanciaképalkotás; $\mathrm{NaF}=$ nátrium-fluorid; $\mathrm{OPG}=$ oszteoprotegerin; $\mathrm{PORP}=$ (partial ossicular replacement prosthesis $)$ részleges hallócsontpótló protézis; RNS = ribonukleinsav; $\mathrm{SNHL}=($ sen sorineural hearing loss) sensorineuralis nagyothallás; SPOT-25 $=$ Stapesplasty Outcome Test 25; TNF = tumornekrózis-faktor; TRT $=$ (tinnitus retraining therapy) tinnitusáthangoló terápia; VEMP $=($ vestibular evoked myogenic potential $)$ vestibularisan kiváltott miogén potenciál; WAI $=$ (wideband acoustic immitance) széles sávú akusztikus immittancia

A középfül legfőbb akusztikai feladata az impedanciaillesztés. Ez a levegő (dobüregi)-folyadék (belső fül) határon bekövetkező, a közegek eltérő hullámellenállásából adódó hangenergia-csökkenés kompenzációját jelenti. Mértéke 24-26-szoros erősítésnek felel meg, mely hangintenzitásban számolva 26,7 dB [1]. Anatómiai alapjait a következők adják (1. ábra):

1. a dobhártya : stapestalp felületi aránya $\left(55 \mathrm{~mm}^{2}\right.$ : $\left.3,2 \mathrm{~mm}^{2}\right)$,

2. a manubrium mallei : crus longum incudis hosszúságának aránya $(1,5: 1)$, valamint

3. a malleus és incus kétkarú emelőrendszer funkciója.

A hallócsontláncolat rezgőképessége, impedanciaillesztő funkciója diszkontinuitás, illetve fixatio esetén alapvetően megváltozik [2].
A hallócsontláncolati fixatiók közül számos érintheti a legkisebb hallócsontot, azaz a stapest, melyeket összefoglaló néven stapesfixatióknak nevezünk. Ezek a betegségek bár audiológiailag egységes tünetcsoport képében jelentkeznek, etiológiai szempontból mégis fontos különbséget tennünk az otoscleroticus, valamint a nem otoscleroticus stapesfixatiók (más néven pseudootosclerosisok) között.

\section{Epidemiológia}

Az otosclerosisnak kizárólag humán manifesztációja ismert. Klinikai incidenciája a kaukázusi populációban $0,3-0,5 \%$-ra becsülhető, post mortem szövettani vizsgálatok adatai alapján azonban a szubklinikus otosclerosis ennél jóval gyakoribb (10-12\%). A vezetéses halláscsökkenések 18-22\%-át okozza [3]. Nőknél mintegy 4-szer gyakrabban fordul elő $[4,5]$.

\section{Etiológia}

Az otosclerosis egy komplex csontremodellinggel járó betegség, melynek létrejöttében genetikai, környezeti és metabolikus tényezőknek egyaránt jelentőségük lehet. Hátterében autoimmun eredet, genetikai betegség, endokrin zavar, valamint a kanyaróvírus szerepe is igazolódott $[4,5]$. A kifejezett nói dominancia a betegségben, valamint az a tény, miszerint a progresszió a terhesség ideje alatt jelentősen gyorsul, felveti a nói nemi hormonokkal való összefüggés lehetőségét. Megfigyelhető familiáris halmozódás autoszomális domináns öröklődésmenettel, azonban 40-45\%-os inkomplett penetranciával [6]. Az ankyloticus stapestalpak szövettani feldolgozásával számos, genetikailag meghatározott tényező szerepe

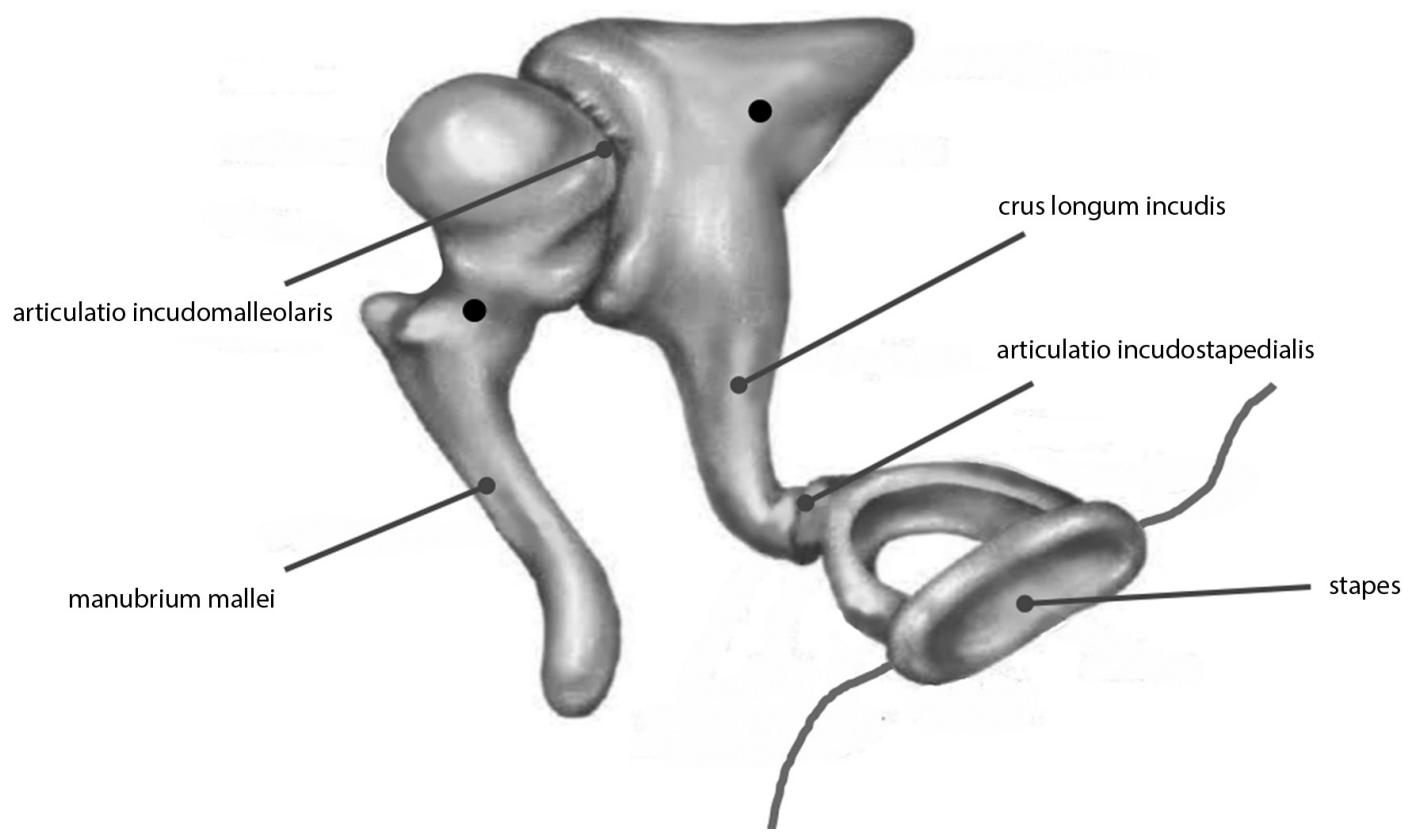

1. ábra | A hallócsontláncolat sematikus anatómiája. (•): A hallócsontláncolat kétkarú emelő rendszerének forgástengelyei 
vetődött fel. Ilyen a reelin extracelluláris mátrixfehérje [6], az I-es típusú kollagén szintézisében fontos COL1gén Al és A2 alléljei [7] vagy az aktív otosclerosissal szoros összefüggést mutató BMP2, 4, 5, 7 csont morfogenetikus fehérjék [8]. A pontos genetikai modell ugyanakkor a mai napig ismeretlen. A renin-angiotenzin-aldoszteron-rendszer szerepe a korábbi felvetésekkel ellentétben nem igazolható [9]. A legkevesebb ellentmondás a kanyaróvírus szerepét illetően tapasztalható, ugyanis az ankyloticus stapestalpakban a virális ágens RNS-e mindig kimutatható, a vírusellenes IgG pedig jellegzetesen csökkent a betegek szérumában. A vírust kötő receptor, a CD46-fehérje humánspecifikus, bizonyos izoformái (os 1-4) csak a szövettanilag is igazolt otoscleroticus stapesfixatiók eseteiben voltak kimutathatók [3].

\section{Klinikai tünetek}

A klinikai tünetek az otoscleroticus fókusz lokalizációjától függnek, melyek alapján elkülönítünk stapedialis/fenestralis, illetve cochlearis/retrofenestralis formát $[4,5]$.

A vezető tünet a lassan progrediáló vezetéses halláscsökkenés (CHL, 80\%), amely kezdetben csak az egyik oldalon jelentkezik, idővel azonban típusosan az ellenoldalon is kialakul. A belsőfül-érintettség jeleként kevert típusú nagyothallás (MHL, 15\%) alakul ki, míg a tisztán sensorineuralis nagyothallás nagyon ritka (SNHL, 5\%). Otosclerosishoz gyakran társul konstans, sistergéshez hasonlító tinnitus (70\%), esetleg vertigo (20\%), amenynyiben a laesio a labyrinthus idegelemeit is érinti. A betegek hallása háttérzajban javulhat (paracusis Willisii) $[4,5,10]$.

\section{Diagnosztika}

\section{Otoszkópos kép}

A fültükri képen folytonos, nívóban álló, transzparens dobhártya látható. Aktív otosclerosis esetén a promontorium vérbő nyálkahártyájának megfelelően esetenként rózsaszínes áttưnés figyelhető meg az intakt dobhártyán át, ez az ún. flamingótünet vagy Schwartze-jel $[4,5]$.

\section{Audiológiai vizsgálatok}

A hagyományos hangvillavizsgálatok is segíthetnek a diagnózis felállításában. Weber-teszt végzésekor vezetéses halláscsökkenés esetén a beteg az érintett oldal felé lateralizál. A Rinne-teszt-negativitás (1024 Hz-en, C3-as hangvillával vizsgálva) legalább 25-30 dBHL-es csontlég-köznek $(\mathrm{ABG})$ felel meg. Gellé-próba során a külső hallójáratban létrehozott nyomás hatására a hangvilla hangja nem változik hallócsontláncolati fixatio esetén $[1,4]$.

A tisztahangküszöb-audiometria során rendszerint tisztán vezetéses vagy kevert típusú halláscsökkenést mé-
Tisztahangküszöb-audiogram

Frekvencia $[\mathrm{Hz}]$

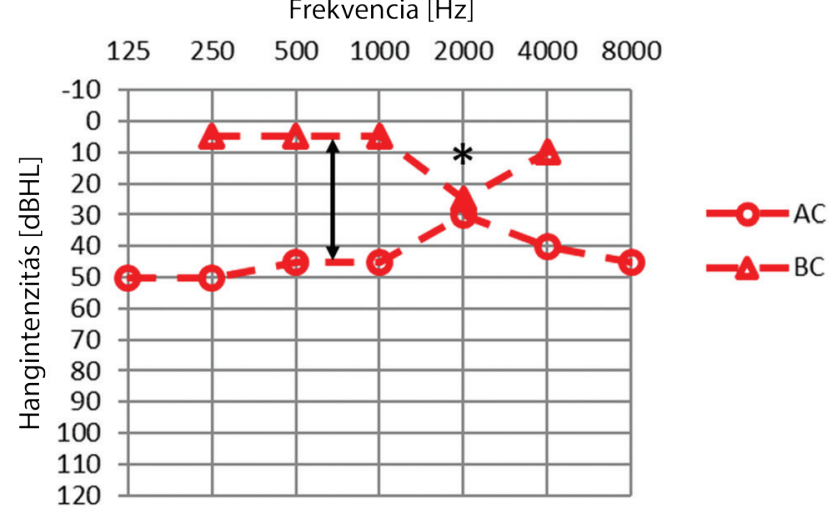

2. ábra

Típusos tisztahangküszöb-audiogram hallócsontláncolati fixatióban. A lég- $(\mathbf{o})$ és csontvezetéses $(\Delta)$ hallásküszöbök szeparációja, az úgynevezett csont-lég-köz (fekete nyíl) jellegzetes lefutást mutat. Emellett szembetúnő a csontvezetéses hallásküszöb látszólagos érintettsége $2 \mathrm{kHz}$-en (úgynevezett Carhart-csipke: fekete ${ }^{*}$ )

rünk, amelynél a légvezetéses hallásküszöb-emelkedés kifejezettebb a mély frekvenciákon. Az otoscleroticus eredetû halláscsökkenések akár 50-60 dBHL-es csontlég-közzel járhatnak. Emellett a csontvezetéses görbén típusos esetben $2000 \mathrm{~Hz}$-en csipkeszerü hallásküszöbemelkedés látható, ez az ún. Carhart-csipke [11, 12]. A pre- és a posztoperatív eredmények leginkább a csontlég-köz értékeinek összehasonlításával jellemezhetők [13] (2. ábra).

Az impedanciavizsgálaton alapuló tympanometriával a középfül funkciója egyszerüen és pontosan megítélhető. A hallócsontláncolati laesiók detektálására multifrekvenciás tympanometria használatára van szükség. A középfül rezonanciafrekvenciája hallócsontláncolati fixatiókban $>1100 \mathrm{~Hz}$ fölé tolódik [14]. A tympanogramon normál dobüregi nyomás és alacsony csúcsú görbe látható („As” vagy „A” típusú görbe) (3. ábra). A stapes ankylosisa

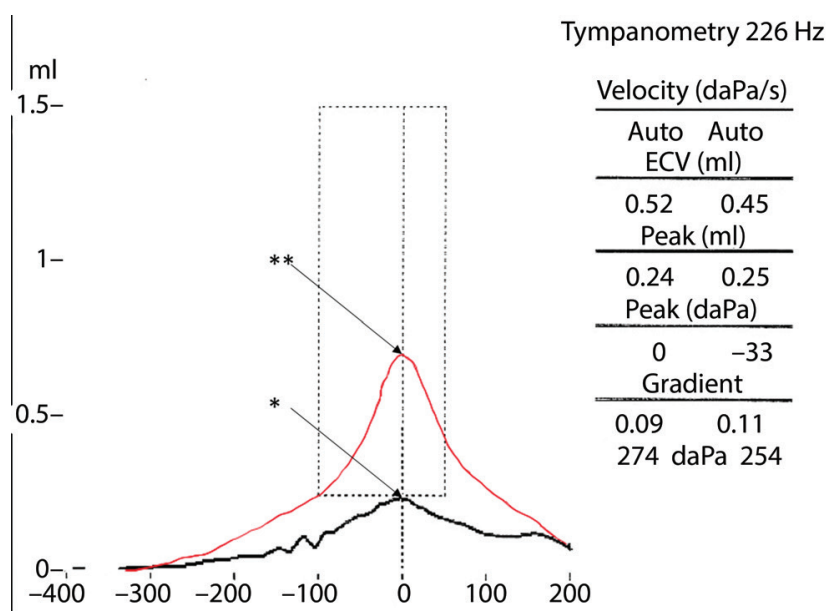

3. ábra Hallócsontláncolati fixatiókban típusos az „As” (fekete görbe, csúcs: *), illetve „A” típusú (piros görbe, csúcs: **) tympanogram, mely vezetéses/kevert típusú halláscsökkenés esetén a középfül normálventilációja mellett szól 
miatt stapediusreflex nem detektálható. Korai stádiumban, még az ABG megjelenése előtt, bifázisos reflexválasz „on-off” jelenség lehet, amely a betegség előrehaladtával eltünik [13].

A széles sávú akusztikus immittancia (WAI-) vizsgálat az eddigieknél érzékenyebb új módszer, amely számszerüsíti az elnyelt és a visszavert energiát a középfülben széles frekvenciatartományon belül. Otoscleroticus fülben szignifikáns reflexiófokozódás látható 400 és 1000 Hz között [13].

\section{Képalkotó vizsgálatok}

A képalkotó vizsgálatok segíthetnek a pontos diagnózis felállításában, amikor a tünetek és az audiológiai lelet alapján a diagnózis nem egyértelmû. A nagy felbontású pyramiscsont-CT (HRCT) alkalmas az olyan apró struktúrák ábrázolására, mint a hallócsontok, illetve a cochlea. Stapedialis otosclerosis aktív stádiumában hypodens fókuszok láthatók a fissula antefenestram körül a demineralizációnak megfelelően. A cochlearis otosclerosis HRCT-képén fénylő, dupla gyürü (halo-jel) látható az oticus capsulában. A progresszió előrehaladtával a sclerosis egyre kifejezettebbé válik, ilyenkor az ovális ablak obliterációja látható $[15,16]$. A cone-beam CT (CBCT) az otosclerosis korai, aktív stádiumát $100 \%$-os szenzitivitással azonosítja, az inaktív stádium diagnosztizálásában azonban mind ez idáig eredménytelennek bizonyult [17].

MR-vizsgálat során a cochlearis otosclerosis Tl-súlyozott képeken izointenzív, T2-súlyozott képeken pedig hiperintenzív jelként ábrázolódik [15]. Elörehaladott esetekben, cochlearis implantátum beültetése előtt, a cochlea lumenének folyadéktere, így az átjárhatósága MRIvel vizsgálható $[15,18]$.

\section{Lézeres Doppler-vibrometria (LDV)}

A hallócsontláncolati fixatio mértékének objektív jellemzésére használható módszer, melynek során egy kis szupermágnest rögzítenek a manubrium malleihez, és egy elektromágneses tekercs hozza mozgásba a hallócsontokat. Az eljárás hátránya, hogy invazív, valamint időigényes. A módszer új alternatívája, a minimálinvazív intraoperatív vibrometria (MIVIB) ezeket a hátrányokat küszöböli ki. Az eredmény értékelése során az incus umbóhoz viszonyított sebességének aránya fordítottan arányos a stapesfixatio fokával [19].

\section{Hisztopatológia}

A pontos diagnózis csak a stapestalp posztoperatív szövettani feldolgozása után mondható ki, amire stapedectomia (a talp teljes eltávolítása) során van lehetőség. A szövettani metszet hematoxilin-eozin (HE) festést követően fénymikroszkóp alatt vizsgálható.
Az otosclerosis a leggyakrabban az embrionális porcot tartalmazó fissula antefenestram, illetve a stapestalp elülső pólusában alakul ki, és innen terjed a környezete felé. A betegség kezdeti, aktív stádiumában a vascularitas és a sejtdússág fokozott, kiszélesedett lacunák és megnagyobbodott osteoclastok láthatók („otospongiosis”). Hozzávetőleg 5-7 év elteltével az aktív gócok kimerülnek, és kialakul az inaktív stádium. Ilyenkor a szövettani képen a cellularitás jelentősen csökkent, a reszorpciós tereket kitölti az újonnan képződött csontszövet $[4,8]$.

Cochlearis otosclerosisban a leggyakrabban a cochlea basalis kanyarulata érintett. A perilymphában megnövekedő citotoxikus enzimek (tripszin, antitripszin, kollagenáz) hatására az oticus capsula és a ligamentum spirale átépül. A szőrsejtek és a ganglion spirale károsodása SNHL-ben nyilvánul meg $[20,21]$.

\section{Differenciáldiagnosztika}

A stapesankylosis egy heterogén betegségcsoport. Hátterében a leggyakrabban otosclerosis áll, ugyanakkor pseudootosclerosis képében számos egyéb kórfolyamat is megjelenhet, mint például (1) temporaliscsont-trauma a kórtörténetben, (2) tympanosclerosis, (3) congenitalis malformatiók, (4) szisztémás csontbetegségek lokális megjelenése, (5) fejlődési rendellenességekhez társuló, ún. szindrómás eltérések, (6) jó-, illetve rosszindulatú daganatok stb. [22-24]. Az ebben a felsorolásban említett betegségeket leszámítva a nem otoscleroticus eredetû stapesfixatiók jelenléte megkérdőjelezhető, leginkább csak diagnosztikus nehézségek miatt létezik ez a külön entitás $[25,26]$.

Külön fontos megemlíteni az úgynevezett harmadikablak-szindrómákat. Ezekben a klasszikus ablakok mellett egy harmadik nyílás (dehiscentia) található a csontos labyrinthuson. Rutin audiológiai vizsgálatokat végezve a kórkép utánozhatja az otoscleroticus eredetű halláscsökkenést, ugyanakkor műtéti ellátása teljesen eltérő, így rendkívül fontos a két betegség elkülönítése, legkésőbb az intraoperatív diagnózis alapján. A diagnózis pontos felállításában a kórtörténet mellett kulcsszerepe van a részletes audiovestibularis kivizsgálásnak (impedanciaaudiometria; vestibularisan kiváltott miogén potenciál [VEMP] vizsgálata). A képalkotók közül a HRCT alkalmazása a legelterjedtebb, de MRI-vel a dehiscentia pontosabban meghatározható $[26,27]$.

\section{Kezelés}

\section{Sebészi terápia}

\section{A stapessebészet története}

A stapes sebészete az 1900-as évektől kezdve folyamatos fejlődésen ment keresztül, míg végül a XX. század középfül-mikrosebészetének sikertörténetévé vált.

Antonio Maria Valsalva 1704-ben írta le elsőként kórbonctani vizsgálatai alapján a stapesfixatiót mint a hallás- 
károsodás okát (munkája „De aure humana tractatus” címmel jelent meg) [28]. Johannes Kessel elsőként végzett stapeseltávolítást 1876-ban, de az antibiotikuméra előtt még súlyos szövődményekkel (labyrinthitis, meningitis) kellett számolni [29]. 1893-ban az osztrák-magyar származású Politzer Ádám szövettani vizsgálatai alátámasztották, hogy a stapesfixatio az oticus capsula primer betegsége [30]. Később a stapedectomia alternatívájaként kerültek bevezetésre a laterális félkörös ívjáraton végzett fenesztrációs technikák. A korszak kiemelkedő alakja Julius Lempert, aki a páciensek többségénél maradandó 20-25 dBHL-es hallásjavulást ért el [31]. Samuel Rosen tért vissza elsóként a stapes mobilizációjához, kiszorítva ezzel a fenesztrációs technikákat [32]. John Shea 1956-ban az eltávolított hallócsontot egy teflonból készült protézissel helyettesítette [5, 33, 34]. Schuknecht 1960-ban fejlesztette ki protézisét: ez egy acéldrótból és zsírszövetből állt, amelyet közvetlenül a mútét közben készített el [34]. A teljes stapestalp eltávolítását (ún. stapedectomia) késóbb felváltotta a talp csupán részleges, posterior harmadának eltávolítása (ún. parcialis stapedectomia). A módszer első alkalmazója Plester volt [35]. Ötletéből kiindulva Shea és Marquet hamarosan már csupán egy apró nyílást készített a stapestalp közepén, melybe egy különleges, piston alakú protézist helyeztek $[36,37]$. Az új eljárás bevezetésével: (1) csökkent a belsőfül-károsodás valószínúsége, (2) javult a magas frekvenciás 'gain', (3) a mély és közepes frekvenciákon javult a csontvezetés, túlzáródás, (4) csökkent a protézisdiszlokáció veszélye, valamint (5) csökkent a labyrinthitis és a perilymphafistula incidenciája [34].

\section{Mütéttipusok}

A mútéttípusok között különbség csak a stapestalp eltávolításának mértékében van. Stapedectomia során a talpat teljesen, parcialis stapedectomiában részlegesen távolítják el, míg stapedotomiában a talpon mindössze egy apró nyílást készítenek. Mindhárom esetben különböző formájú és anyagú piston protézisekkel pótolható a hallócsont, ezzel a hallócsontláncolat folytonossága és mobilitása helyreállítható (ossiculoplastica). Ma szinte kizárólag stapedotomia a választandó eljárás, hiszen ebben az esetben a legkisebb a belsőfül-károsodás valószínúsége. Lézer alkalmazásával a mútét során a vérzés minimalizálható, és a mútétet esetlegesen követő szédülés mértéke is csökken. Ma már lehetőség van a mútétet endoszkópos úton is elvégezni $[4,38]$.

\section{Mütéti indikációk, kontraindikációk}

Indikáció: (1) ép dobhártya, (2) tisztahangküszöb-audiometria során a beszédfrekvenciákon mért legalább 25 dBHL-es csont-lég-köz, (3) az érintett oldali fül 1024 Hz-es (C3-as) hangvillával vizsgálva Rinne-próba-negatív, (4) tympanometriával „As” vagy „A” típusú görbe regisztrálható, (5) stapediusreflex nem váltható ki, (6) multifrekvenciás tympanometriával a rezonanciafrekvencia $1000 \mathrm{~Hz}$ feletti, (7) VEMP-vizsgálattal a harmadikablak-szindróma kizárható $[4,13]$. Kétoldali otosclerosisban először a rosszabbul halló fül mútétét célszerú elvégezni, majd az ellenoldali fül műtétére legalább l év különbséggel és csak akkor kerülhet sor, amennyiben az első mütét eredményes és szövődménymentes volt.

Kontraindikáció: (1) rossz általános állapot, (2) akut otitis media vagy a tuba auditiva funkciózavara az érintett oldalon, (3) egyetlen halló fül esetén mútét nem végezhető, illetve (4) ha a beteg elutasítja a mútétet.

\section{Mütéti eredmények}

A mútéti hallásrehabilitáció nem szünteti meg az otosclerosis okát, mégis jó hallásteljesítménnyel hosszú évtizedekre panaszmentessé válhat a páciens. A preoperatív csont-lég-köz mértéke akár 50-60 dBHL lehet. A mútét sikeres, ha posztoperatívan ez az érték a beszédfrekvenciákon (500-2000 Hz) 10 dBHL alatt záródik, míg a siker megkérdőjelezhető, ha az ABG a 20 dBHL-t meghaladja [39-42]. A Carhart-csipke a posztoperatív audiogramon gyakran eltünik (4. ábra).

\section{Lehetséges szövödmények}

A mútét után hallásjavulás hozzávetőleg 95\%-ban várható, míg az esetek 1-2\%-ában számolhatunk kifejezett belsőfül-károsodással és következményes SNHL-lel. A posztoperatív időszakban viszonylag gyakran megjelenhet átmeneti vertigo, tinnitus és egyéb vegetatív panaszok. Ugyanakkor a súlyos komplikációk ritkák. A mütét folyamán sérülhetnek a nervus facialis motoros ágai vagy a chorda tympani. Az incus a mütét bármelyik lépése során szubluxálódhat (a leggyakrabban a piston rögzítésekor). Az embrionális arteria stapedialis nem megfelelő regressziója jelentős vérzést okozhat mütét során. A mútétet ebben az esetben abba kell hagyni, mert az érnek szerepe lehet akár a központi idegrendszer kerin-

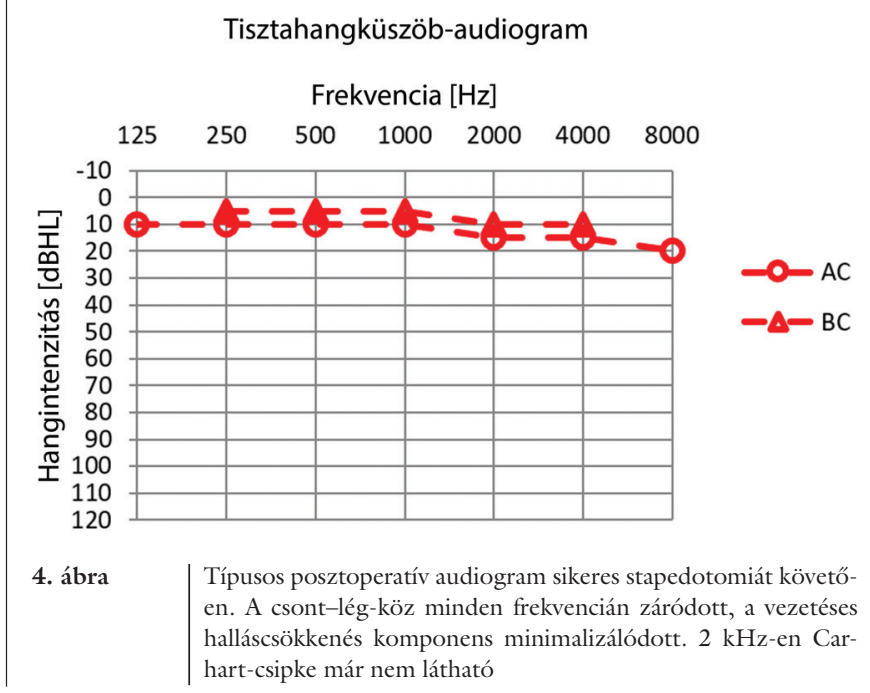
en. A csont-lég-köz minden frekvencián záródott, a vezetéses
halláscsökkenés komponens minimalizálódott. $2 \mathrm{kHz}$-en Carhart-csipke már nem látható 
gésében is. Továbbá a mútét során perilympha törhet fel, illetve a letört talprészlet besodródhat a vestibulum cochleaeba (lebegő stapestalp). Obliterativ otosclerosisban burjánzó csontszövet és kifejezetten megvastagodott, kemény stapestalp látható $[4,38,40,43]$.

A belső fül károsodása szintén előfordulhat. Szignifikánsnak tekintjük a legalább $15 \mathrm{dBHL}$-es progressziót [39]. A posztoperatív szövődmények közül a legsúlyosabb a teljes hallásvesztés, amely stapedotomia után az esetek kevesebb mint 2\%-ában jelentkezik, és gyakoribb revíziós mútétet követóen vagy obliterativ otosclerosisban. Megjelenhet késői típusú (posztoperatív 4-10. nap) paresis nervi facialis. Fontos késői szövődmény az incus processus lenticularisának nekrózisa és a piston másodlagos diszlokációja, aminek idegentest-reakció vagy a protézis túl erôs megszorítása lehet az oka. Sebészi fertózések nagyon ritkák stapedotomiát követően [42, 43$]$.

\section{Pistontipusok}

A pistonok a stapessebészetben alkalmazott, rendkívül változatos speciális protézisek [5]. Általános követelmény a pistonokkal kapcsolatban, hogy legyenek biokompatibilisak, eredeti formájukat hosszú évek elteltével is őrizzék meg, ne bomoljanak le, és MR-vizsgálat hatására se mozduljanak el. A protézis rögzítésének módja a mütét legfontosabb lépése. Túl gyenge rászorítást követően a hangvezetés nem lesz tökéletes, ún. „loose wire” szindróma alakul ki torz, időben hullámzó hallással. A túl erôs zárás pedig veszélyeztetheti az incus mucosalis vérellátását. A manuálisan végzett rögzítés legnagyobb hátránya, hogy a szorítóerő a csonton nem egyformán oszlik el $[39,44]$. A legújabb hőmemóriás önzáródó pistonok a manuális rászorítást hivatottak kiküszöbölni. Ezek a típusok legalább $45^{\circ} \mathrm{C}$-os hő (lézer vagy más hőforrás) hatására visszanyerik eredeti, zárt alakjukat, és a kontaktpontokon egyenletes erővel rögzülnek az üllőn, így nem okoznak túlzáródást. Sok tanulmány foglalkozik a különböző pistonok összehasonlításával, a hosszú távú követési idő korlátozottsága miatt azonban nehéz megítélni, hogy melyikük használata a legmegfelelőbb [39, $40,44]$. Az incus hosszú szárán rögzített teflonpiston intraoperatív képe az 5. ábrán látható.

Az autogén corticalis csontcolumella (ACBC) alternatív megoldás arra, hogy protézis helyett lehet saját csontgrafttal is pótolni a stapest. A fasciával befedett foramen ovale és az incus hosszú szára közé helyezett csontdarabokat (két rövid típusú columella, vagyis PORP) ionomer cementtel összeragasztva áthidalható a csonthiány. Ezzel a technikával is megfelelő hosszú távú eredmények érhetők el [42, 45].

\section{GIC alkalmazása a stapessebészetben}

Az üvegionomer cement (GIC) fehér pasztaszerü anyag, amely néhány perc alatt megköt, és jól hasznosítható a középfülsebészetben kötőanyagként. A GIC felhasznál-

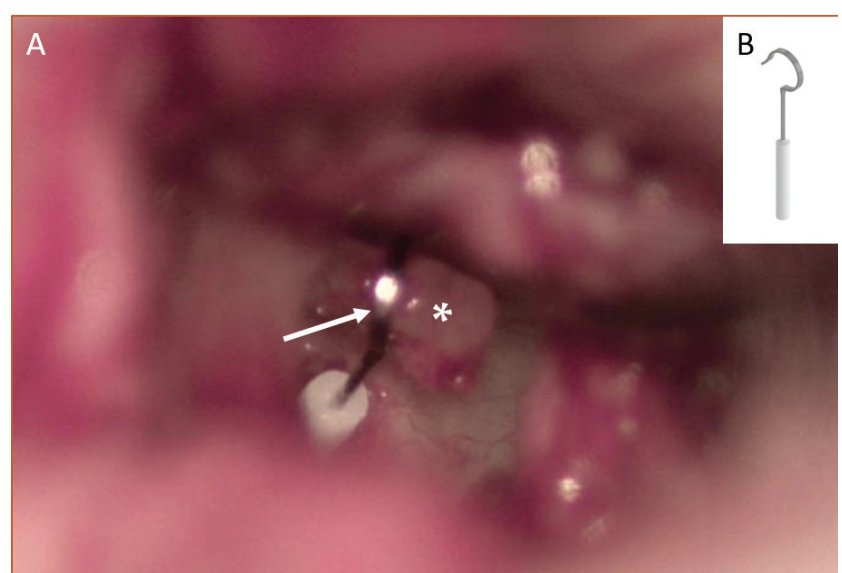

5. ábra $\mid$ A: az incus hosszú szárán (fehér *) rögzített teflonpiston intraoperatív helyzete (fehér nyíl) látható. B: saját klinikai gyakorlatunkban a leggyakrabban alkalmazott teflonpiston

ható a felhelyezett protézis rögzítésére, a sorvadt incus rekonstruálására, illetve a columellák összeillesztésére $[42,46,47]$.

\section{Hallásjavitó implantátumok}

A hallásjavító implantátumok ideális megoldást jelenthetnek olyan középfülbetegségek esetén is, mint az otosclerosis. Súlyos fokú, kevert típusú nagyothallás esetén középfül-implantátum a stapedotomiával egy ülésben beültethető [48]. A csontvezetéses implantátumok képesek a középfület megkerülve a koponyacsontok megrezegtetésén keresztül közvetlen jelátvitelt biztosítani. Jelentősen előrehaladott otoscleroticus esetekben cochlearis implantátumokkal (CI) lehet sikert elérni $[13,38]$. Otosclerosisban az elektróda beültetése során a kerek ablak elcsontosodása vagy a scala tympani ossificatiója nehézséget okozhat [21].

\section{Nem sebészi terápia}

\section{Hallókészülékek}

A betegtájékoztatás során mindenképpen fel kell világosítani a beteget, hogy milyen egyéb lehetőségek állnak rendelkezésre, amennyiben nem vállalja a mútéti hallásrehabilitációt. Azokban a ritka esetekben, amikor a hallás javulása elmaradt a várt eredménytôl, esetleg a hallás tovább romlik a mütéti beavatkozást követően, szintén megoldást jelentenek a panaszokra a hagyományos légvezetéses készülékek. Bizonyos indikációkban (például krónikus otitis externa, hallójárati allergia) szóba jöhet szemüvegszárba épített csontvezetéses hallásjavító készülékek adása is. Ez utóbbi ugyanakkor csak relatíve jó sensorineuralis funkció mellett nyújt kellő hallásrehabilitációt. 


\section{Gyógyszeres kezelés}

Bár az elmúlt évtizedek kutatásai során számos, csontanyagcserét befolyásoló hatóanyag merült fel kezelési lehetőségként, a sebészi terápia hatékonyságát idáig egyikkel sem sikerült felülmúlni. A nátrium-fluorid $(\mathrm{NaF})$ a korai, aktív stádiumban bizonyítottan hatásos azáltal, hogy gátolja az osteoclastaktivációt és a csontátépülést. A biszfoszfonátok a csontok hidroxilapatitjához kötődve az előzőhöz hasonló mechanizmussal képesek az osteoclastokban apoptózist előidézni. A bioflavonoidok a foszfodiészteráz-gátláson keresztül főként a tinnitus kezelésében lehetnek potenciálisan hatékonyak. A vitaminok közül a D-vitamin szerepe a legjelentősebb, mert meghatározó szerepet játszik a csontanyagcsere szabályozásában, emellett gyulladáscsökkentő hatása is ismert $[49,50]$. Szintén a korai, gyulladásos stádiumban lehet megkísérelni antiinflammatoros szerek alkalmazását [49]. A jövőben szerepe lehet a célzott, biológiai terápiának, például a rekombináns oszteoprotegerinnek (OPG), illetve az anti-TNF-szereknek is. Az antiosteoporoticus gyógyszerek (denoszumab) postmenopausában lehetnek eredményesek. Az egyik legkevésbé vitatott patogenetikai faktor, a kanyaróvírus elleni immunizáció az eddigi eredmények alapján sikeresen feltartóztathatja az otosclerosis progresszióját [49].

\section{Életminőség}

Az otosclerosis, mint az összes halláskárosodással járó betegség, a betegeket a szociális izolációval fenyegeti. Egy 2017-ben készült németországi felmérés szerint a stapesmútéten átesettek életminősége (HRQOL) jelentôs javulást mutatott minden mért paraméteren. A Stapesplasty Outcome Test 25 (SPOT-25) segítségével átfogó kép nyerhető az életminőség javulására vonatkozóan, mert integrálja a posztoperatív audiometriai adatokat és a betegek szubjektív visszajelzéseit [51]. A tinnitus a betegek számára legalább olyan zavaró panasz lehet, mint a halláskárosodás. Stapedotomiát követően a fülzúgás valamelyest javulhat, amennyiben nem, akkor tinnitusáthangoló terápia (TRT) javasolható számukra. A TRT egy kombinált terápia, melynek során pszichológiai konzultációk, illetve zajgenerátor vagy tinnitusprogrammal rendelkező, speciális hallókészülék alkalmazásával a habituáció elérése a cél [13].

\section{Következtetés}

Otosclerosisban csökken a középfül akusztikusimpedancia-illesztő, -erősítő funkciója, ezáltal jellemzően progresszív, vezetéses típusú halláscsökkenéshez vezet. Részletes anamnézisfelvételt követően az otosclerosis feltételezett diagnózisa már hagyományos audiológiai vizsgálatokkal (hangvillavizsgálat, tisztahangküszöbaudiometria, valamint tympanometria) is felállítható. A korszerú képalkotó vizsgálatok a nem otoscleroticus stapesfixatiók differenciáldiagnosztikájában segítenek eligazodni. Az évtizedek alatt tökéletesedő fülsebészeti technikának, a fejlődő eszközparknak köszönhetően az otosclerosis sikeresen kezelhető betegséggé vált.

Anyagi támogatás: A közlemény megírása, illetve a kapcsolódó kutatómunka anyagi támogatásban nem részesült.

Szerzôi munkamegosztás: K. F.: A kézirat megszövegezése, irodalomkutatás. R. L.: A mútétek elvégzése, a kézirat lektorálása. K. J. G.: Szakmai ellenőrzés, a kézirat lektorálása. J. J. A.: A kézirat megszövegezése, illetve korrektúrája, témavezetés. A cikk végleges változatát valamennyi szerző elolvasta és jóváhagyta.

Érdekeltségek: A szerzőknek nincsenek érdekeltségeik.

\section{Köszönetnyilvánítás}

A szerzők köszönetüket fejezik ki a vizsgálatokban részt vevő audiológiai szakasszisztenseknek.

\section{Irodalom}

[1] Pytel J. (ed.) Audiology. [Audiológia.] Victoria Kiadó, Pécs, 1996. [Hungarian]

[2] Farahmand RB, Merchant GR, Lookabaugh SA, et al. The audiometric and mechanical effects of partial ossicular discontinuity. Ear Hear 2016; 37: 206-215.

[3] Karosi T, Liktor B, Csomor P, et al. Detection of otosclerosis associated measles virus receptor $(\mathrm{cd} 46)$ isoforms at protein level - genetic model for otosclerosis. [Az otosclerosisra jellemzó kanyaróvírusreceptor (cd46) variánsok fehérjeszintû kimutatása - az otosclerosis genetikai modellje.] Fül-, orr-, gégegyógyászat (Otorhinol Hung.) 2012; 58: 53-59. [Hungarian]

[4] Sziklai I. Otosclerosis. In: Répássy G. (ed.) Otorhinolaryngology head and neck surgery. [Otosclerosis. In: Répássy G. (szerk.) Fül-orr-gégészet, fej-nyak-sebészet.] Medicina Könyvkiadó, Budapest, 2011; pp. 117-121. [Hungarian]

[5] Ribári O. (ed.) Otorhinolaryngology head and neck surgery. [Fül-orr-gégészet - fej-nyak-sebészet.] Medicina Könyvkiadó, Budapest, 1997. [Hungarian]

[6] Csomor P, Liktor B, Sziklai I, et al. The role of reelin in the pathogenesis of otosclerosis. [A reelin expresszió szerepe az otosclerosis patogenezisében.] Fül-, orr-, gégegyógyászat (Otorhinol Hung.) 2012; 58: 101-106. [Hungarian]

[7] Csomor P, Liktor B, Liktor B, et al. No evidence for disturbed COLlAl and A2 expression in otosclerosis. [Nincs bizonyíték a COLlAl és A2 allélek kóros expressziójára otosclerosisban.] Fül-, orr-, gégegyógyászat (Otorhinol Hung.) 2013; 59: 10-15. [Hungarian]

[8] Csomor P, Liktor B, Liktor B, et al. The bone morphogenetic proteins (BMP2, 4, 5, 7) show the correlation of histological activity of otosclerotic foci. [A csontmorfogenetikus fehérjék (BMP2, 4, 5, 7) expressziója összefüggést mutat az otosclerosis szövettani aktivitásával.] Fül-, orr-, gégegyógyászat (Otorhinol Hung.) 2013; 59: 121-126. [Hungarian]

[9] Liktor B, Csomor P, Szász CsS, et al. No evidence for the expression of renin-angiotensin-aldosterone system in otosclerotic stapes footplates. [Nincs bizonyíték a renin-angiotenzin-aldoszteron rendszer expressziójára otoszklerotikus stapestalpakban.] 
Fül-, orr-, gégegyógyászat (Otorhinol Hung.) 2014; 60: 38-43. [Hungarian]

[10] Behrbohm H, Kaschke O, Nawka T, et al. (eds.) Ear, nose, and throat diseases with head and neck surgery. 3rd edition. Thieme, Stuttgart, 2009.

[11] Carhart R. Bone conduction advances following fenestration surgery. Trans Am Acad Opthamol Otolaryngol. 1952; 56: 621629.

[12] Chhan D, Bowers P, McKinnon ML, et al. Middle-ear and innerear contribution to bone conduction in chinchilla: the development of Carhart's notch. Hear Res. 2016; 340: 144-152.

[13] Danesh AA, Shahnaz N, Hall JW 3rd. The audiology of otosclerosis. Otolaryngol Clin North Am. 2018; 51: 327-342.

[14] Jóri J, Kiss JG, Czigner J. Multifrequency tympanometry in the diagnostics of ossicular chain fixation and discontinuity. [Multifrekvenciás tympanometria a hallócsont-láncolati fixáció és megszakadás diagnosztikájában.] Fül-, orr-, gégegyógyászat (Otorhinol Hung.) 1995; 41: 142-146. [Hungarian]

[15] Wolfovitz A, Luntz M. Impact of imaging in management of otosclerosis. Otolaryngol Clin North Am. 2018; 51: 343-355.

[16] Purohit B, Hermans R, Op de Beeck K. Imaging in otosclerosis: a pictorial review. Insights Imaging 2014; 5: 245-252.

[17] Liktor B, Karosi T, Révész P, et al. Diagnostic value of conebeam CT in histologically confirmed otosclerosis. [A cone-beam CT diagnosztikus értéke a szövettanilag igazolt otosclerosis eseteiben.] Fül-, orr-, gégegyógyászat (Otorhinol Hung.) 2014; 60 90-94. [Hungarian]

[18] Abdurehim Y, Lehmann A, Zeitouni AG. Stapedotomy vs cochlear implantation for advanced otosclerosis: systematic review and meta-analysis. Otolaryngol Head Neck Surg. 2016; 155 : 764-770.

[19] Wales J, Gladiné K, Van de Heyning P, et al. Minimally invasive laser vibrometry (MIVIB) with a floating mass transducer - a new method for objective evaluation of the middle ear demonstrated on stapes fixation. Hear Res. 2018; 357: 46-53.

[20] Cureoglu S, Baylan MY, Paparella MM. Cochlear otosclerosis. Curr Opin Otolaryngol Head Neck Surg. 2010; 18: 357-362.

[21] Eshraghi AA, Ila K, Ocak E, et al. Advanced otosclerosis. Stapes surgery or cochlear implantation? Otolaryngol Clin North Am. 2018; 51: 429-440.

[22] Gülşen S. Promontory osteoma mimicking otosclerosis: case report. J Laryngol Otol. 2019; 133: 1107-1109.

[23] Ramdoo K, Dale OT, Herdman RC. Malleo-incudal osteoma: an unexpected finding during surgery for presumed otosclerosis. J Laryngol Otol. 2011; 125: 968-969.

[24] Yoon YS, Yoon YJ, Lee EJ. Incidentally detected middle ear osteoma: two cases reports and literature review. Am J Otolaryngol. 2014; 35: 524-528.

[25] Quesnel AM, Ishai R, Cureoglu S, et al. Lack of evidence for nonotosclerotic stapes fixation in human temporal bone histopathology. Otol Neurotol. 2016; 37: 316-320.

[26] Ward BK, Carey JP, Minor LB. Superior canal dehiscence syndrome: lessons from the first 20 years. Front Neurol. 2017; 8 : 177.

[27] Beyazal Celiker F, Özgür A, Celiker M, et al. The efficacy of magnetic resonance imaging for the diagnosis of superior semicircular canal dehiscence. J Int Adv Otol. 2018; 14: 68-71.

[28] Yale SH. Antonio Maria Valsalva (1666-1723). Clin Med Res. 2005; 3: 35-38.

[29] Heermann H. Johannes Kessel and the history of endaural surgery. Arch Otolaryngol. 1969; 90: 652-658.

[30] Mudry A. Adam Politzer (1835-1920) and the description of otosclerosis. Otol Neurotol. 2006; 27: 276-281.

[31] Pietruski J. Juliusz Lempert (1890-1959): the author of the fenestration technique. [Juliusz Lempert (1890-1959) - twórca fenestracji.] Otolaryngol Pol. 1998; 52: 341-346. [Polish]

[32] Pietruski J. Samuel Rosen (1897-1981): the originator of stapes mobilization. [Samuel Rosen (1897-1981) - odkrywca mobi- lizacji strzemiaczka.] Otolaryngol Pol. 1999; 53: 739-742. [Polish]

[33] Nazarian R, McElveen JT Jr, Eshraghi AA. History of otosclerosis and stapes surgery. Otolaryngol Clin North Am. 2018; 51: 275-290.

[34] Gjuric M, Rukavina L. Evolution of stapedectomy prostheses over time. Adv Otorhinolaryngol. 2007; 65: 174-178.

[35] Plester D. Advances in the microsurgery of the ear during the last 10 years. [Fortschritte in der Mikrochirurgie des Ohres in den letzten 10 Jahren.] HNO 1970; 18: 33-40. [German]

[36] Shea JJ, Sanabria F, Smyth GD. Teflon piston operation for otosclerosis. Arch Otolaryngol. 1962; 76: 516-521.

[37] Marquet J. Deafness syndrome due to stapedial prosthesis deficiency. [Le syndrome de surdité dû à une déficience de le prothèse stapédienne.] Soc Fr ORL CR Sci Congr. 1965: 151-160. [French]

[38] Révész P, Harmat K, Háromi I, et al. Special cases of stapes surgery - case reports and literature review. [Különleges stapes sebészeti megoldások - esetismertetések és irodalmi áttekintés.] Fül-, orr-, gégegyógyászat (Otorhinol Hung.) 2016; 62: 9-16. [Hungarian]

[39] Gerlinger I, Bakó P, Révész P, et al. KTP laser stapedotomy with a thermal shape-memory Nitinol piston: follow-up study reporting intermediate-term hearing. [KTP lézer stapedotomia hőmemóriás önzáródó Nitinol pisztonnal: retrospektív klinikai tanulmány a középtávú halláseredmények bemutatásával.] Fül-, orr-, gégegyógyászat (Otorhinol Hung.) 2014; 60: 1-6. [Hungarian]

[40] Gersdorff M, Gérard JM. (eds.) Atlas of middle ear surgery. Georg Thieme Verlag, Stuttgart, 2011.

[41] Gurr A, Sudhoff H, Hildmann H. Approaches to the middle ear. In: Middle Ear Surgery. Springer Verlag, Berlin, Heidelberg, 2006, pp. 19-23.

[42] Gerlinger I. The use of laser technology and ionomer cement in middle ear surgery: clinical and experimental studies. [Lézertechnológia és ionomer cement alkalmazása a középfülsebészetben: klinikai és experimentális vizsgálatok.] Fül-, orr-, gégegyógyászat (Otorhinol Hung.) 2015; 61: 75-84. [Hungarian]

[43] Antonelli PJ. Prevention and management of complications in otosclerosis surgery. Otolaryngol Clin North Am. 2018; 51: 453-462.

[44] Révész P, Nepp N, Harmat K, et al. Comparison of hearing results following the use of NiTiBOND versus Nitinol prostheses in stapes surgery: a retrospective controlled study reporting short-term postoperative result. [Rövidtávú halláseredmények retrospektív összehasonlítása NiTiBOND, illetve Nitinol stapes protézissel végzett stapedotomiákat követően.] Fül-, orr-, gégegyógyászat (Otorhinol Hung.) 2017; 63: 110-114. [Hungarian]

[45] Bauer M, Gerlinger I, Pytel J, et al. Long-term results of the use of autogenous cortical bone columellas to replace the stapes at stapedectomy. [A stapes-pótló autogén corticalis csontcolumellákkal elért hosszú távú eredmények.] Fül-, orr-, gégegyógyászat (Otorhinol Hung.) 2010; 56: 203-209. [Hungarian]

[46] Ráth G, Burián A, Somogyvári K, et al. Should the ossicle be denuded prior to the application of glass ionomer cement? [Szükséges-e a hallócsontot denudálni üvegionomer cement alkalmazása előtt?] Fül-, orr-, gégegyógyászat (Otorhinol Hung.) 2015; 61: 141-146. [Hungarian]

[47] Ráth G, Bakó P, Révész P, et al. Application of ionomer cement onto the stapedial footplate: impact on the perilymphatic aluminium level. An experimental study on animals. [Glass ionomer cement alkalmazása a stapes talpán: a perilympha alumínium szintjének állatkísérletes vizsgálata.] Fül-, orr-, gégegyógyászat (Otorhinol Hung.) 2016; 62: 17-21. [Hungarian]

[48] Burian A, Gerlinger I, Tóth T, et al. Stapedotomy with incus vibroplasty - A novel surgical solution of advanced otosclerosis and its place among existing therapeutic modalities - Hungarian 
single institutional experiences. Auris Nasus Larynx 2020; 47 $55-64$.

[49] Liktor B, Szekanecz Z, Batta JT, et al. Perspectives of pharmacological treatment of otosclerosis. [Az otosclerosis gyógyszeres kezelési lehetőségeinek áttekintése.] Fül-, orr-, gégegyógyászat (Otorhinol Hung.) 2013; 59: 2-9. [Hungarian]

[50] de Oliveira Penido N, de Oliveira Vincente A. Medical management of otosclerosis. Otolaryngol Clin North Am. 2018; 51: $441-452$.
[51] Lailach S, Schenke T, Baumann I, et al. Living with otosclerosis: disease-specific health-related quality-of-life measurement in patients undergoing stapes surgery. Eur Arch Otorhinolaryngol. 2018; 275: 71-79. [Epub 2017 Nov 7]

(Kriston Fanni dr., Budapest, Lemberg u. 46., 1171 e-mail: fanni.kriston@gmail.com)

"Nihil non aut domat diuturnitas."

(Nincs, mit az idő múlása nem enyhít vagy el nem mulaszt.)

Az Orvosi Hetilap 2020, 161, 560. oldalán (14. szám) megjelent OH-Kvízre három helyes megfejtés érkezett.

A beküldők: Dr. Bíró László (Budapest), Dr. Janik Leonárd (Budapest) és Dr. Somogyi Erzsébet (Budapest).

A nyerteseknek szívből gratulálunk.

Nyereményüket - egy, az Akadémiai Kiadó webáruházában kedvezményes vásárlásra jogosító kupont - e-mailen küldjük el.

A cikk a Creative Commons Attribution 4.0 International License (https://creativecommons.org/licenses/by/4.0/) feltételei szerint publikált Open Access közlemény melynek szellemében a cikk bármilyen médiumban szabadon felhasználható, megosztható és újraközölhető, feltéve, hogy az eredeti szerző és a közlés helye, illetve a CC License linkje és az esetlegesen végrehajtott módosítások feltüntetésre kerülnek. (SID_1) 